\title{
The
}

\section{PAN-PACIFIC ENTOMOLOGIST}

First record of Serropalpus substriatus Haldeman, 1848 (Coleoptera: Melandryidae) on giant sequoia, Sequoiadendron giganteum (Lindl.) J. Buchholz (Cupressaceae): New larval host

Kim S. Camilli, Natural Resources Management \& Environmental Sciences, 11-217, California Polytechnic State University, San Luis Obispo, California 93407; e-mail: kcamilli@calpoly.edu (corresponding author); Joshua D. Soderlund, Natural Resources Management \& Environmental Sciences, 11-217, California Polytechnic State University, San Luis Obispo, California 93407; e-mail: jdsoder@hotmail.com; David Wood, Department of Environmental Science, Policy and Management, University of California, 130 Mulford Hall, Berkeley, California 94720; e-mail: bigwood@berkeley.edu; Jim Kral, California Department of Forestry and Fire Protection, P.O. Box 517, Springville, California 93265; e-mail: JimKral@fire.ca.gov;

Douglas D. Piirto, Department of Natural Resources Management \& Environmental Sciences, 11-217, California Polytechnic State University, San Luis Obispo, California 93407; e-mail: dpiirto@calpoly.edu 


\section{Scientific Note}

\section{First record of Serropalpus substriatus Haldeman, 1848 (Coleoptera: Melandryidae) on giant sequoia, Sequoiadendron giganteum (Lindl.) J. Buchholz (Cupressaceae): New larval host}

An adult of Serropalpus substriatus Haldeman, 1848 (Colepotera: Melandryidae) was reared from a giant sequoia, Sequoiadendron giganteum (Lindl.) J. Buchholz (Cupressaceae), log obtained from a dead tree at Mountain Home Demonstration State Forest, Tulare County, California $\left(36^{\circ} 13^{\prime} 29.5^{\prime \prime} \mathrm{N}, 118^{\circ} 40^{\prime} 06.0^{\prime \prime} \mathrm{W}, 2049 \mathrm{~m}\right)$. Though several species of melandryids live under the bark and in the wood of dead trees (DeLeon 1952), only $S$. substriatus is recorded as having economic importance in western forests. This species is widely distributed in North America where it breeds in various coniferous trees. In the West, hosts include red fir, Abies magnifica A. Murray bis (Pinaceae); incense-cedar, Calocedrus decurrens (Torr.) Florin (Cupressaceae); lodgepole pine, Pinus contorta Loudon (Pinaceae); ponderosa pine, Pinus ponderosa Douglas Lawson \& C. Lawson (Pinaceae); redwood, Sequoia sempervirens (Lamb. Ex D. Don) Endl. (Cupressaceae); Port-Orford-cedar, Chamaecyparis lawsoniana (A. Murray bis) Parl (Cupressaceae); Engelmann spruce, Picea engelmannii Engelm. (Pinaceae); and Douglas-fir, Pseudostuga menziesii (Mirb.) Franco (Pinaceae) (Furniss \& Carolin 1977, Ross 1968). In British Columbia, the species also commonly infests felled white spruce, Picea glauca (Moench) Voss (Ross 1968).

Two young giant sequoias died in the month of August at Mountain Home Demonstration State Forest: one in 2009 and a second in 2010 (Soderlund 2012). Tree deaths were very rapid occurring within one month as determined by crown fade. Trees were approximately 47 and 34 years old, respectively. The giant sequoia that died in 2010 had multiple round exit holes extending from the base of the tree to approximately $2 \mathrm{~m}$ in height. Six round wood sections, each $30 \mathrm{~cm}$ in height, were collected starting at the base of the tree and taken back to San Luis Obispo, CA on 24 August 2010. These sections were covered with a $0.033-\mathrm{cm}$ thick woven fiberglass mesh screening with openings $1 \mathrm{~mm} \times 1 \mathrm{~mm}$ in size. The mesh was wrapped around the entire log sections with the ends of the screening folded over and stapled and then covered in duct tape to ensure any emerging insects would not escape. These rounds were then stored inside at room temperature for observation and checked every 3-4 weeks for emerging insects.

On 27 October 2010, one adult Serropalpus substriatus was collected from one round wood section (Fig. 1). Species identification was completed by Cheryl Barr, Senior Museum Scientist/Collection Manager of the Essig Museum of Entomology at the University of California, Berkeley and further confirmed by Dr. Darren Polluck, Head Curator of Eastern New Mexico University. To confirm if this insect had been recorded previously on giant sequoias, we referred to relevant works (Furniss \& Carolin 1977; Hartesveldt et al. 1975; Harvey et al. 1976; Piirto 1977, 1994; Piirto et al. 1998; Stecker 1980) and queried eleven entomological collections in California (California Academy of Sciences; California State Collection of Arthropods, California Department of Food \& Agriculture; Bohart Entomology Museum, University of California-Davis; Entomology Research Museum, University 


\section{CA: Tulare County Springville, Mountain Home Demo. St. Forest 27-X-2010, K. Camilli \\ reared from Sequoiadendron giganteum}

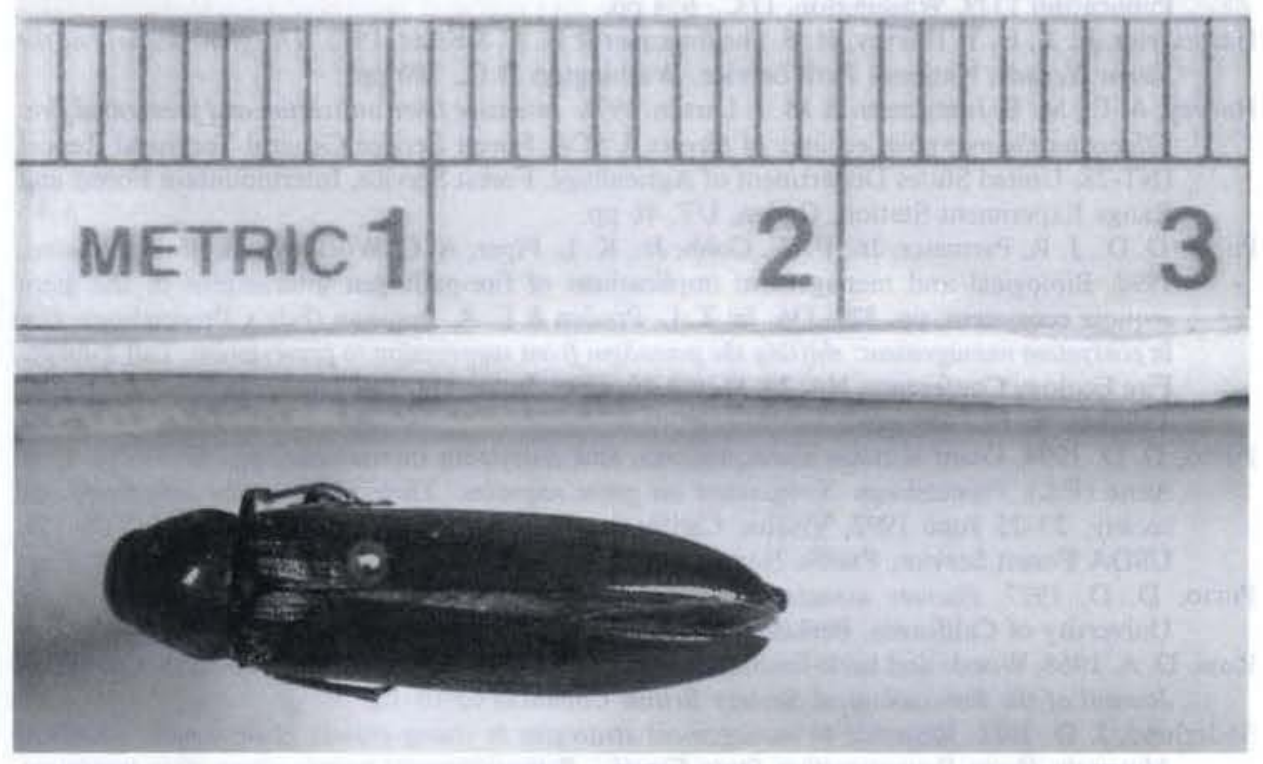

Figure 1. Adult Serropalpus substriatus reared from Sequoiadendron giganteum.

of California-Riverside; Santa Barbara Museum of Natural History; Natural History Museum of Los Angeles County; San Diego Natural History Museum; Cornell University; National Forest Service Library; Essig Museum of Entomology, University of California, Berkeley; and Sequoia-Kings Canyon insect collection) as well as two experts on Melandryidae (Darren Polluck from Eastern New Mexico University and Dan Young from University of Wisconsin). We found no evidence of $S$. substriatus being previously reared from or collected on giant sequoia.

Thus, this represents a new larval host of Serropalpus substriatus reared from giant sequoia. The voucher specimen is deposited at the Essig Museum of Entomology at the University of California-Berkeley.

Kim S. Camilli, Natural Resources Management \& Environmental Sciences, 11-217, California Polytechnic State University, San Luis Obispo, California 93407; e-mail: kcamilli@calpoly.edu (corresponding author); Joshua D. Soderlund, Natural Resources Management \& Environmental Sciences, 11-217, California Polytechnic State University, San Luis Obispo, California 93407; e-mail: jdsoder@hotmail.com; David Wood, Department of Environmental Science, Policy and Management, University of California, 130 Mulford Hall, Berkeley, California 94720; e-mail: bigwood@berkeley.edu; Jim Kral, California Department of Forestry and Fire Protection, P.O. Box 517, Springville, California 93265; e-mail: JimKral@fire.ca.gov; 
Douglas D. Piirto, Department of Natural Resources Management \& Environmental Sciences, 11-217, California Polytechnic State University, San Luis Obispo, California 93407; e-mail:dpiirto@calpoly.edu

\section{Literature Cited}

DeLeon, D. 1952. Insects associated with Sequoia sempervirens and Sequoia gigantea in California. The Pan-Pacific Entomologist 23:75-91.

Furniss, R. L. \& V. M. Carolin. 1977. Western forest insects. USDA Forest Service Miscellaneous Publication 1339, Washington, D.C., 654 pp.

Hartesveldt, R. J., H. T. Harvey, H. S. Shellhammer \& R. E. Stecker. 1975. The giant sequoia of the Sierra Nevada. National Park Service, Washington D.C., 180 pp.

Harvey, A. E., M. E. Juergensen \& M. J. Larsen. 1976. Intensive fiber utilization and prescribed fire: Effects on the microbial ecology of forests. USDA Forest Service General Technical Report INT-28. United States Department of Agriculture, Forest Service, Intermountain Forest and Range Experiment Station, Ogden, UT, 46 pp.

Piirto, D. D., J. R. Parmeter, Jr., F. W. Cobb, Jr., K. L. Piper, A. C. Workinger \& W. J. Otrosina. 1998. Biological and management implications of fire-pathogen interactions in the giant sequoia ecosystem, pp. 325-336. In: T. L. Pruden \& L. A. Brennan (Eds.). Proceedings. Fire in ecosystem management: shifting the paradigm from suppression to prescription. Tall Timbers Fire Ecology Conference, No. 20, May 7-10, 1996, Boise, ID; Tall Timbers Research Station, Tallahassee, FL, 459 pp.

Piirto, D. D. 1994. Giant sequoia insect, disease, and ecosystem interactions, pp. 82-89. In: P. S. Aune (Ed.). Proceedings. Symposium on giant sequoias: Their place in the ecosystem and society, 23-25 June 1992, Visalia, California; General Technical Report. PSW-GTR-151. USDA Forest Service, Pacific Northwest Station, Albany, CA, 179 pp.

Piirto, D. D. 1977. Factors associated with tree failure of giant sequoia. Ph.D. Dissertation. University of California, Berkeley.

Ross, D. A. 1968. Wood- and bark-feeding Coleoptera of felled spruce in interior British Columbia. Journal of the Entomological Society British Columbia 65:10-12.

Soderlund, J. D. 2012. Response to management strategies in young-growth giant sequoia stands at Mountain Home Demonstration State Forest - Remeasurement twenty years after treatment. M.S. Thesis. California Polytechnic State University, San Luis Obispo.

Stecker, R. E. 1980. Chapter 6. Arthropods associated with the giant sequoia, pp. 69-82, 152-162. In: H. T. Harvey, H. S. Shellhammer \& R. E. Stecker (Eds.). Giant sequoia ecology, fire and reproduction. Scientific Monograph Series 21. U.S. Department of Interior, National Park Service, Washington, D.C., 182 pp.

Received 10 Apr 2012; Accepted 14 Aug 2012 by F. W. Shockley; Publication date 19 Nov 2012. 